\title{
Characterization of the starting materials for functionally graded thermoelectric materials for pseudobinary system of $\mathrm{Bi}_{2} \mathrm{Te}_{3}-\mathrm{Sb}_{2} \mathrm{Te}_{3}$
}

\author{
Charakterystyka materiałów wyjściowych \\ do materiałów gradientowych układu pseudobinarnego $\mathrm{Bi}_{2} \mathrm{Te}_{3}-\mathrm{Sb}_{2} \mathrm{Te}_{3}$
}

\author{
KAMILA JANUSZKO \\ RAJU CHETTY \\ TSUTOMU MASHIMO \\ KRZYSZTOF WOJCIECHOWSKI *
}

\author{
DOI: $10.17814 /$ mechanik.2016.5-6.67 \\ Międzynarodowa Konferencja IMT 2016
}

Samples of Bi-Sb-Te system were prepared by solid state synthesis from pure elements, microstructure and thermoelectric properties were characterized. From obtained powders segmented samples were constructed in order to confirm change of the thermoelectric properties with composition. Segmented element is expected to have better efficiency.

KEYWORDS: thermoelectric materials, energy conversion efficiency, functionally graded materials, segmented materials

Próbki otrzymane w wyniku syntezy z czystych pierwiastków zostały scharakteryzowane pod względem mikrostruktury i właściwości termoelektrycznych. Z otrzymanych proszków skonstruowano element segmentowy i potwierdzono zmianę właściwości termoelektrycznych ze zmianą składu chemicznego. Przewiduje się podwyższoną sprawność takiego elementu.

SŁOWA KLUCZOWE: materiały termoelektryczne, sprawność konwersji energii, funkcjonalne materiały gradientowe, materiały segmentowe

Thermoelectric materials are currently one of the most promising in the field of waste heat recovery [1] and cooling devices that does not require maintenance.

Their reliability is their strong point, however there is a lot of room left for improvement in the area of their efficiency $[2 \div 3]$. Common approach is to construct segmented materials which are formed from layers made of different materials. It allows increase in the thermoelectric figure of merit ZT of even $50 \%$.

Even though effective, there are issues of joints which are affecting both the mechanical properties and the efficiency decrease in these areas. Moreover, designing of the comprehensive segmented element is a very complex task. Therefore authors of this paper have decided to verify whether preparation of the segmented element by creating the sample from layers made of $\mathrm{Bi}-\mathrm{Sb}$-Te system with different nominal compositions. As it was reported by Jiang et al [4] depending on the chemical composition of this system, significant difference in thermoelectric could be observed. As a result the preparation of the segmented material from

\footnotetext{
* Mgr inż. Kamila Januszko (kamila.januszko@gmail.com) - Wydział Inżynierii Materiałowej i Ceramiki, Akademia Górniczo-Hutnicza; Institute of Pulsed Power Kumamoto University, Japan; PhD Raju Chetty (chettyraj@gmail.com) - Wydział Inżynierii Materiałowej i Ceramiki, Akademia Górniczo-Hutnicza; prof. Tsutomu Mashimo (mashimo@gpo.ac.jp) - Institute of Pulsed Power Kumamoto University, Japan; prof. dr hab. inż. Krzysztof T. Wojciechowski (wojciech@agh.edu.pl) - Wydział Inżynierii Materiałowej i Ceramiki, Akademia Górniczo-Hutnicza
}

such a material should allow significant improvement of the thermoelectric element (TE) performance over certain temperature range. Segmented material could still leave some room for improvement if we observe distinctive barriers between the TE layers. Therefore the next step would be creation of the functionally graded thermoelectric material. It was revealed by Mashimo that if strong gravitational field is applied, sedimentation of atoms in solid state material could be observed. It would be the best solution for this challenge as obtaining gradation in the material using typical techniques of sedimentation would not ensure sedimentation within whole sample depth/length of the material and the amount of parameters for controlling the process emerges in high expectations for the method.

The preliminary research on the Bi-Sb system was made and just recently it was reported that [5] in this system chemical composition, band gap and thermoelectric properties were proven to appear in a good. agreement with each other. Therefore preparation of the materials using the aforementioned method in special ultracentrifuge apparatus in elevated temperatures under the acceleration of the over $10^{6} \mathrm{G}$ seems to be exceptionally promising for the improvement in the energy conversion efficiency in thermoelectric materials.

\section{Experimental}

Ingots of $\left(\mathrm{Bi}_{2} \mathrm{Te}_{3}\right)_{x}\left(\mathrm{Sb}_{2} \mathrm{Te}_{3}\right)_{1-x}$ were prepared by synthesis from pure elements in stoichiometric ratio in rocking furnace in the temperature of around $1020 \mathrm{~K}$, followed by quenching. Thereafter samples were annealed in $673 \mathrm{~K}$ for $168 \mathrm{~h}$. Powders obtained from ingots were sintered using Field Assisted Sintering Technique (FAST) and analyzed by $X-R a y$ Diffraction (XRD). Microstructure and chemical composition of prepared samples were characterized using Scanning Electron Microscopy (SEM) equipped with Energy Dispersive Spectroscopy (EDS), whilst thermoelectric properties were analyzed using four-probe method, scanning thermoelectric microprobe (STM) and Laser Flash Analysis (LFA).

Samples were sintered as uniform and segmented elements with layers of different compositions in order to compare their thermoelectric properties. Segmented elements were prepared in a one step process. These were made by putting the layers of powders with different compositions into a die and sintering with FAST.

\section{Results and discussion}

From the XRD data (Fig. 1., exemplary results), it was concluded that main phase belongs to crystal structure 
of $\mathrm{Sb}_{2} \mathrm{Te}_{3}$. Elemental composition of prepared samples obtained from EDS was in agreement with nominal composition.

Thermoelectric properties of materials with composition $x=0.17,0.23$ and 0.26 are being presented in Fig. 2 (electrical conductvity), Fig. 3 (Seebeck coefficient), Fig. 4 (thermal conductivity).

Electrical conductivity of the samples is increasing with the increase of the bismuth content which might be due to the anti-structural defects as it was reported earlier in other work on this system [4]. However with further increase in bismuth content electrical conductivity is decreasing, which might be caused by generation of electrons by some further defects. All of the samples showed that with the increase of temperature electrical conductivity decreases, which indicates metallic-like behavior of the samples, which could also be observed in heavily doped semiconductors.

Seebeck coefficient of the samples reveals positive values for all of the samples ( $p$-type material), which indicated that the majority of the carriers is in the form of holes. Moreover it follows similar pattern as electrical conductivity in accordance to the same phenomenon - as with increase in the amount of carriers we should be able to observe reverse behavior - increase in electrical conductivity and decrease in Seebeck coefficient. This is in good agreement with data reported previously.

Thermal conductivity in ideal case would have stable vaue, however we might observe the slight decrease of this parameter. In this system atoms of $\mathrm{Bi}$ and $\mathrm{Sb}$ are having large mass difference therefore decrease in thermal conductivity may be caused by increase of phonon scattering induced by mass fluctuation scattering. Furthermore, with increase of temperature apart from electronic thermal conductivity and lattice thermal conductivity additional ambipolar thermal conductivity which is a combination of previous two might be observed and this may, on contrary, induce the increase in overall thermal conductivity. This is probably the cause of the increase observed at higher temperatures for the data presented in Fig. 4. All of presented data are in relatively good agreement with data presented in [4]

To compare the properties of the material for construction of the segmented element, sample was prepared with the powders of $x=0.14,0.20$ and 0.26 with the step of $x=0.06$ between the composition of the layers in order to confirm noticeable change in the properties.

It was revealed by STM results that in the segmented samples Seebeck coefficient values varies according to the composition of each layer along the sample length, while in uniform materials such behavior is not observed. In the Fig. 5 aforementioned dependence for the segmented element is presented.

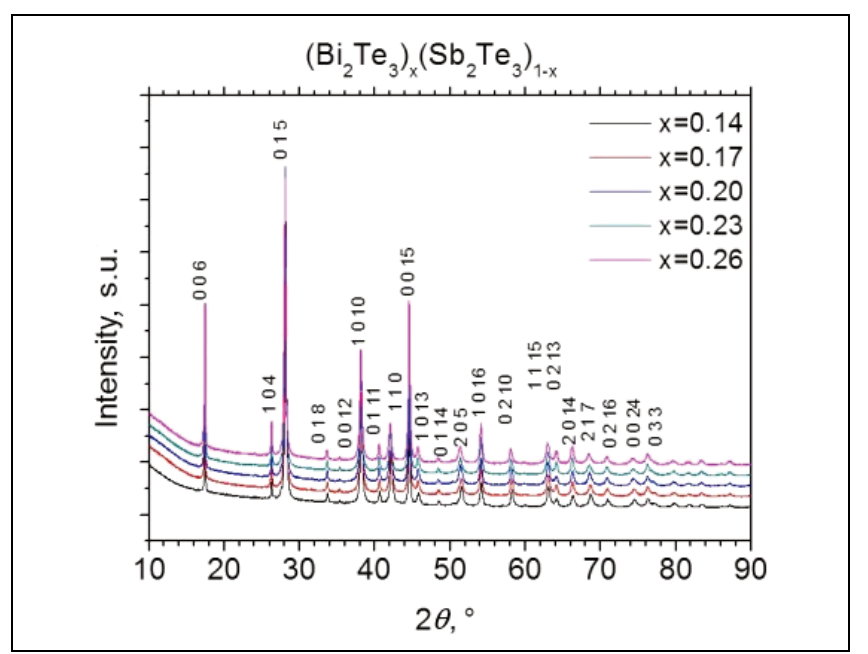

Fig. 1. XRD of the prepared samples $\left(\mathrm{Bi}_{2} \mathrm{Te}_{3}\right)_{\times}\left(\mathrm{Sb}_{2} \mathrm{Te}_{3}\right)_{1-x}$

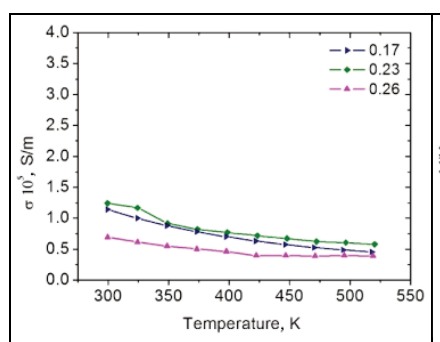

Fig. 2. Electrical conductivity of the $\left(\mathrm{Bi}_{2} \mathrm{Te}_{3}\right)_{x}\left(\mathrm{Sb}_{2} \mathrm{Te}_{3}\right)_{1-x}$ samples

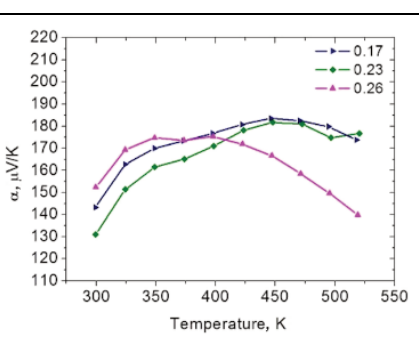

Fig. 3. Seebeck coefficient of the $\left(\mathrm{Bi}_{2} \mathrm{Te}_{3}\right)_{x}\left(\mathrm{Sb}_{2} \mathrm{Te}_{3}\right)_{1-x}$ samples

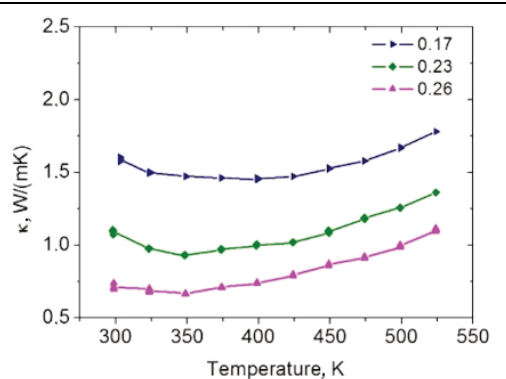

Fig. 4. Thermal conductivity of the $\left(\mathrm{Bi}_{2} \mathrm{Te}_{3}\right)_{x}\left(\mathrm{Sb}_{2} \mathrm{Te}_{3}\right)_{1-x}$ samples

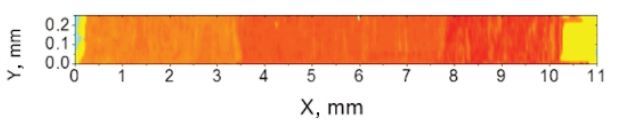

$0 \quad 25 \quad 50 \quad 75100125150175200225250275300325350$

Fig. 5. Segmented material

\section{Conclusions}

Presented results revealed that production of the segmented material from Bi-Sb-Te system is possible using simple solid state metallurgy. Even with slight change of the chemical composition thermoelectric properties follow this feature with good agreement, therefore further investigation is promising. It is expected that the segmented materials will be having better efficiency and functionally graded materials made with this system could enhance it more. It would be valuable to continue increasing desired energy conversion efficiency by using more advanced techniques for production of thermoelements, e.g. sedimentation of atoms in strong gravitational field.

The project has been partially supported by the National Science Centre project No. 2012/05/N/ST8/03390.

\section{LITERATURE}

1. Romanjek K., Vesin S., Aixala L., Baffie T., Bernard-Granger G., Dufourcq J. „High-Performance Silicon-Germanium-Based thermoelectric Modules for Gas Exhaust Energy Scavenging". J. Electron. Mater. Vol. 44, No. 6 (2015): pp. 2192 $\div 2202$.

2. Seifert W., Müller E., Walczak S. „Local optimization strategy based on first principles of thermoelectrics". Physica Status Solidi A. Vol. 205, No. 12 (2008): pp.2908 $\div 2918$.

3. Ishida A., Thao H.T.X., Yamamoto H., Kinoshita Y., Ishikiriyama M., "Thermoelectric conversion efficiency in IV-VI semiconductors with reduced thermal conductivity". AIP Advances. Vol. 5, No. 10 (2015): pp.107135-1 $\div 107135-7$.

4. Jiang J.,Chen L., Bai S., You Q., Wank Q. „Thermoelectric properties of $p$-type $\left(\mathrm{Bi}_{2} \mathrm{Te}_{3}\right)_{\times}\left(\mathrm{Sb}_{2} \mathrm{Te}_{3}\right)_{1-x}$ crystals prepared via zone

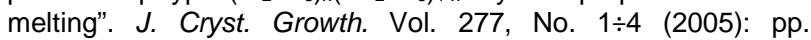
$258 \div 268$.

5. Januszko K., Stabrawa A., Ogata Y., Tokuda M., Khandaker J.I., Wojciechowski K., Mashimo T. „Influence of Sedimentation of Atoms on Structural and Thermoelectric Properties of Bi Sb Alloys". J. Electron. Mater. DOI: 10.1007/s11664-0154307-2. 